\title{
Om Grundtvigs historiesyn
}

\author{
Af William Michelsen
}

I sin disputats »Menneske først -« har sognepræst dr. theol. Kaj Thaning i en note til kapitlet »Verdenshistorie « påvist, at en anekdote om den gamle Grundtvig, som jeg i slutningen af indledningskapitlet til min disputats »Tilblivelsen af Grundtvigs historiesyn« anfører efter en artikel af dr. Holger Kjare, er hentet fra en artikel af Ernst Trier i det skrift, der blev udgivet af Fr. Rønning i hundredåret for Grundtvigs fødsel, og at fortællingen dér har en lidt afvigende form. Ernst Trier spurgte Grundtvig om, hvordan han skulde fortælle bibelhistorie for sine nye elever på Blaagaard Seminarium, og Grundtvig svarede, at han skulde fortælle om mennesket som skabt og faldet, men bestemt til genoprejsning til et evigt liv. Jeg havde - efter Holger Kjær - refereret historien, som om Trier havde spurgt, hvordan han skulle fortælle historie, og som om Grundtvig i sit svar havde sagt, at mennesket var »genfødt« til et evigt liv.

Forskellen er naturligvis ikke ligegyldig, og det er i sandhedens og videnskabens interesse, at den er blevet påpeget. For Thaning ligger det væsentlige $i$, at $\mathrm{Gr}$. i denne forbindelse ikke taler om mennesket som genfødt til et evigt liv, men kun som bestemt til genoprejsning. For mig er det lige så vigtigt, at Gr.s svar ikke gælder verdenshistorien, men kun bibelhistorien. Derved siger den nemlig ikke noget om den gamle Gr.s historiesyn i almindelighed, men kun om hans syn på, hvordan man bør fortælle bibelhistorie. Den kan derfor ikke bruges til at illustrere den opfattelse, jeg i min disputats hævder, nemlig at Gr. til sin død fastholdt den bibelske betragtning af verdenshistorien.

Men den kan heller ikke bruges til at modbevise den. Og jeg har da også kun anført den som ét blandt mange vidnesbyrd om, at Grundtvig ikke opgav det bibelske historiesyn som sin personlige livsanskuelse, selv om han i 1833 definitivt opgav det forsøg på at bevise sandheden af det bibelske historiesyn videnskabeligt, som han på forskellig måde havde gjort i sine tre Verdenskrøniker fra I8I2, I8I4 og I8I7. 
Da Thaning imidlertid stadig hævder, at denne opfattelse er fejlagtig, idet Grundtvig i sin Haandbog i Verdens-Historien I, I833, så at sige har skiftet historiesyn og dermed livssyn, er det nu nødvendigt direkte at imødegå Thanings opfattelse. Han skriver (Dansk Udsyn I964 s. 452), at min opfattelse af Grundtvigs historiesyn er »fuldstændig korrekt, når det drejer sig om den unge Grundtvig«. Han tilføjer imidlertid, henvendt til mig: »Men De kan da ikke mene, at synet $\mathrm{i}$ den store håndbog svarer dertil! «

Jo, det er netop, hvad jeg mener. Men først må jeg minde om, at min disputats handler om den unge Grundtvig, og at jeg kun i slutningen af indledningskapitlet (og lejlighedsvis andre steder i mine to bøger) har udtalt mig om den senere (den modne) Grundtvig. Jeg har hele tiden vidst, at Thaning havde en afvigende opfattelse af dette punkt i Grundtvigs forfatterskab; men jeg mener stadig ikke, at min opfattelse er uforenelig med Thanings hovedtesis: at det menneskelige er forudsætningen for det kristelige i den modne Grundtvigs livssyn, og at denne ejendommelighed blev Grundtvig bevidst i 1832 .

Ganske ligesom Thaning mener jeg, at Grundtvig var modstander af enhver form for »gnosticisme«, som han kalder det i sit brev til mig i Dansk Udsyn. Ved gnosticisme forstår jeg en religion, hvori frelsen vindes gennem en åbenbaret mystisk viden, hvorved mennesket hæver sig op over materien til en rent åndelig verden, og hvori Jesu liv, død og opstandelse ikke opfattes som historiske begivenheder, men kun som symboler på menneskets hæven sig fra det legemlige til det åndelige. Det var netop en sådan opfattelse, Grundtvig i r8ro vendte sig imod bl. a. hos Schelling, således i fortalen til sin dimisprædiken, hvor han erklærer, at det er hans overbevisning, »at Siælens Hiem, hvorefter den dog saa saare længes, er utilgængeligt for al jordisk Viden, og at den kun paa Troens Vinger kan løfte sig did.«(US II s. I2). Følgerne af denne erklæring har Grundtvig kun meget langsomt indset. Men hele hans følgende udvikling kan betragtes som en konsekvens af den.

Thaning har imidlertid med fuldkommen ret fremhævet den begejstring, Grundtvig i i. bind af Haandbog i Verdens-Historien udtrykker for den græske historieskriver Polybios, der var født et par hundrede år før Kristus, og som åbenbart for Grundtvig nu blev den vigtigste repræsentant for »den Græske Betragtning af Menneske-Livet og Historien«, altså den, han i fortalen kalder »den Bedste, der paa vort nærværende Stade lader sig videnskabelig grundfæste og giennemføre«, og som han derfor her foretrækker »til Skole-Brug«, som det hedder. Men 
når Grundtvig på det sted i selve fremstillingen, hvor lovprisningen af Polyb når sit højdepunkt, udtrykkelig gør et meget sigende forbehold: »naar vi undtage Moses, er der i hele Historien ikke en eneste Mand, han fra alle Sider kan sammenlignes med « - fremhævelserne er Grundtvigs egne, og forbeholdet gentages i næste punktum - så er dette lille forbehold tilstrækkeligt til at vise berettigelsen af min påstand: vel forsøger Grundtvig at indtage et almenmenneskeligt »græsk s synspunkt over for historien; men det forhindrer ham dog ikke $\mathrm{i}$ at fastholde det »mosaisk-christelige« som det »eneste guddommelig sande og eviggiældende - i overensstemmelse med fortalens ord, der jo er nedskrevet - og trykt - efter resten af bogen.

Thaning citerer stedet fuldkommen korrekt (Menneske først - s. 323, jf. Haandbog i Verdens-Historien I, I833, s. 565, US VI 450); men i hans fremstilling virker det, som om han læser hen derover. Vel læser han yderst opmærksomt - ingen tvivl om det - ud fra sit eget synspunkt. Men det er også nødvendigt at gå ind på et andet synspunkt end sit eget. For min del har jeg forsøgt dette ved i indledningen til min disputats (kapitlet »Problemstilling «) at sige, at mit problem kunde løses på to måder. Jeg har valgt den ene og derefter forsøgt at kontrollere mine resultater ved at stille dem over for modargumenter fra den anden løsning. Når Thaning ikke har gjort noget tilsvarende, er det nødvendigt at gøre opmærksom på modargumenterne i den påfølgende debat.

Når Thaning kalder Grundtvigs udvikling hans »opgør med sig selv«, finder jeg det yderst træffende. Jeg tillader mig imidlertid at udvide denne betegnelse til at gælde også tiden for 1832. Jeg vil altså ikke nægte, at der findes spor af den schellingske »gnosticisme« hos Grundtvig efter I8Io. Hvad jeg hævder, er blot, at Grundtvig modarbejder dem hos sig selv. Og i dette selvopgør er påvirkningen fra Luther efter min opfattelse en positiv faktor, fordi det bl. a. er Luther, der har lært ham at opfatte Bibelen historisk og ikke gnosticistisk.

Det er denne opfattelse, jeg har påvist i Grundtvigs Verdenskrøniker. Men Thaning har ganske ret $i$, at den træder tilbage $i$ hans senere historieskrivning. Årsagen er, som jeg har vist, at han først i I833 opstiller et klart skel mellem tro og viden. Alligevel vedbliver der hos Grundtvig at være en nær forbindelse mellem tro og historieskrivning (som enhver læser af håndbogen vil kunne mærke). Af to grunde:

I) fordi al historieskrivning må bygge på en vis tiltro til de historiske kilder, historikeren anvender - en erkendelse, som er Grundtvig fuldt bevidst, og som jeg et sted har udtrykt ved at skrive: »Man kan 
ikke bygge historieforskning på tvivl.« (Den sælsomme forvandling i N. F. S. Grundtvigs liv s. 230).

2) fordi Grundtvig som historieskriver hverken kan eller vil skjule sin kristne tro. - Den ene grund svækker ikke den anden.

Om det fra et teologisk synspunkt kan siges, at Grundtvig fra 1833 》sækulariserer sit historiesyn « - som Thaning hævder det - kan jeg ikke udtale mig om. Fra et ikke-teologisk, idéhistorisk synspunkt må det benægtes, og det gælder særlig, når man - som jeg - hævder, at Grundtvigs historiesyn samtidig er hans personlige livsanskuelse. Den omstændighed, at han $\mathrm{i}$ håndbogen vælger en ikke-bibelsk betragtning som den bedste $i$ et videnskabeligt arbejde, hindrer ham ikke $i$ at bevare den »mosaisk-christelige Anskuelse« som sin personlige livsanskuelse.

For Thaning er det væsentligt at understrege, at det menneskelige er forudsætningen for det kristelige. For mig er det væsentligere at bestemme, hvordan Grundtvig nærmere definerer det at være menneske. I indledningen til Nordens Mythologi gør han det på en måde, der er bestemt til at vise, hvad han kunde være enig med H. N. Clausen og de øvrige »Naturalister« om. Jeg har i Dansk Udsyn ( Ig64 s. 442) omskrevet det således: »ikke et sækulariseret, internationalt, humanistisk menneskebegreb, men kristendommens opfattelse af mennesket som skabt i Guds billede, fristet af djævelen og faldet for fristelsen, men ved Jesu evangelium dog i stand til at bevæge sig hen imod det mål, det oprindelig af Gud var bestemt til at virkeliggøre.« - Thaning svarer herpå: »Kort og godt: dette »menneskebegreb《 er De ikke i stand til at påvise nogetsteds hos Grundtvig.« - Men jeg må altså henvise til selve Nordens Mythologi 1832 (US V 40I-403) og kan, som man vil forstå, ikke undre mig over, at Thaning synes, at min udtryksmåde »minder mest om den tro, som Grundtvig fandt hos sine kirkelige modstandere (H. N. Glausen).«(Dansk Udsyn I964 s. 450).

Det eneste punkt i mit arbejde, Thaning har kunnet rokke, er altså den anekdote, jeg har anbragt som slutvignet $\mathrm{i}$ indledningskapitlet til min disputats, og dermed står og falder mit ræsonnement om den modne Grundtvig ikke. Og hvis man ikke vil nøjes med de klare principielle udtalelser, jeg allerede i min disputats og her påny har fremdraget, så vil jeg gerne gøre opmærksom på, at Grundtvig også i 2. bind af håndbogen på lignende måde som i Verdenskrønikerne genfortæller Jesu liv, fx. med følgende ord:

».. og nu begyndte fesus at vandre om i Landet, og viste sig $\mathrm{i}$ alle Maader, 
som den omspaaede Christus, i hvis Dage Blinde skulde see, Döve höre, Halte gaae, Spedalske renses, Döde staae op og Fattig-Folk spörge gode Tidender «. (Haandbog i Verdens-Historien II, 1836, s. 22-23, US VI 558).

Sådan skriver kun en historiker, der både selv er overbevist om, at Det gamle Testamentes Messias-profetier er opfyldt i Jesus, og som ikke kan lade være at meddele denne overbevisning, også når han har sat sig for at skrive en verdslig statshistorie.

Det bibelske historiesyn slår igennem, også når Grundtvig vælger at foretrække en almenmenneskelig betragtning af historien. Dette viser sig allertydeligst i de bemærkninger, Grundtvig i samme kapitel har indført om Det nye Testamente som historisk kilde (rimeligvis under indtryk af den opsigt, D.F. Strauss i 1835 havde gjort med sit værk: »Das Leben Jesu«):

»... paa Indvendingerne, Man nys i Mængde har gjort mod Paalideligheden deraf, kan vi her ikke indlade os, da de ikke grunde sig paa andre gamle Efterretninger, men ene og alene paa Urimeligheden, Man vil have fundet deri, at Fesus skulde være Guds Sön mere end andre Mennesker.« - I det fölgende opruller Gr. hele det bibelske historiesyn, som det er fremstillet af Paulus: skabelse, syndefald, oprejsning ved Jesus Kristus, idet »Ebræerne« indskydes som det $»$ Prophetiske Folk «, der var bestemt »til at arbeide paa Opreisningen «, og dernæst udvikles forskellen mellem den »naturlige « og den »overnaturlige« opfattelse af den måde, hvorpå »Guddoms-Manden ... kan frelse Slægten«. Grundtvig fortsætter: »den Ebraiske Anskuelses Rigtighed, Christi Guddom og hans Magt til at opvække aandelig Döde, de hvile urokkelig i Christendommens bekiendte Virkninger i Verden, der nödvendig maae have haft en saadan Aarsag, da de ellers var udeblevet《. (HV II r 836, s. 29-30, US VI s. 563-64). - Stedet er typisk for Gr.s tankegang (jf. Henning Høirup: Grundtvigs Syn paa Tro og Erkendelse, 1949).

Enhver kan slå efter og se, om Thaning har ret, når han skriver: »Her mangler jo helt Paulus's historiesyn, tanken om Guds opdragelse og om historien som menneskets frelseshistorie.« (Dansk Udsyn I964 s. 452).

For at citater fra bind III ikke skal savnes, henviser jeg til US VII s. 379-8o og fra det tillæg, der vedføjedes i i869, til samme bind s. 703 . Det er rigtigt, at der, som Thaning skriver, »er noget, der hedder menneskets uomgængelige vilkår«. Grundtvig satte sig i 18 I3 for at holde en række forelæsninger herom, der først er udgivet af $\mathrm{Hal} \mathrm{Koch}$ i 2. bind af Værker i Udvalg (jf. Nordisk tidskrift 1946, hvor jeg har gennemgået denne manuskriptgruppe). Den bog om emnet, Grundtvig havde planlagt, blev i stedet til de filosofiske betragtninger i DanneVirke 1816-19, hvortil der foreligger yderst interessante udkast, som 
viser, at Grundtvig har givet både sin videnskab og sin digtning et erkendelsesteoretisk underlag, som adskiller sig væsentligt fra samtidens gængse tanker, omend det er sat i relation dertil. Kun en konfrontation af disse betragtninger med den modne Grundtvigs tanker vil vise, $\mathrm{i}$ hvilken udstrækning frigørelsen i i $830 e r n e$ var et brud med det grundlag, der i årene 18 I3 og derefter blev lagt for Grundtvigs tanker om mennesket og historien.

Da jeg ikke selv er teolog af uddannelse, har jeg betegnet mig som »humanist«. Af livsanskuelse er jeg derimod kristen og anser ikke dette for at være nogen hindring for at drive forsvarlig idéhistorisk videnskab. Om Grundtvig vilde jeg derimod ikke bruge ordet »humanist«, dels fordi han var teolog af uddannelse, dels fordi han i Verdenskrøniken 18 1 2 udtrykker en skarp kritik af de videnskabsmænd, der i den nyere tid havde dyrket faggruppen »humaniora (US II 403) i en lang note om »den kristne Newton«. Læst og forstået i sin sammenhæng er denne note iøvrigt meget oplysende m. h. t. udgangspunktet for Grundtvigs opgør med sin egen fortid. 